\title{
BAKTERI ASOSIASI PADA KARANG SCLERACTINIA KAITANNYA DENGAN FENOMENA LA-NINA DI PULAU BUNAKEN
}

\author{
ASSOCIATED BACTERIA OF SCLERACTINIAN CORAL IN CONNECTION WITH PHENOMENA \\ OF LA-NINA IN BUNAKEN ISLAND
}

\author{
Eghbert Elvan Ampou, Iis Triyulianti dan Suciadi C. Nugroho \\ Kementerian Kelautan dan Perikanan - Balai Penelitian dan Observasi Laut \\ Tim Perubahan Iklim, Jl. Baru Perancak, Negara-Jembrana, Bali 82251, Indonesia \\ E-mail : elvan.ampou@gmail.com, iis_triyulianti@yahoo.com, suciadi_cn@gmail.com
}

Diterima tanggal: 25 Februari 2014, diterima setelah perbaikan: 24 April 2015, disetujui tanggal: 27 Mei 2015

\begin{abstract}
ABSTRAK
Penelitian tentang karang keras (Scleractinian coral) yang terkontaminasi bakteri relatif masih kurang dilakukan khususnya di perairan Indonesia. Untuk itu dilakukan kegiatan penelitian di Taman Nasional Bunaken pada dua periode yakni Mei 2010 (musim peralihan I) dan Agustus 2011 (Monsoon II). Penelitian ini difokuskan pada kontaminasi bakteri gram positif (+) dan gram negatif (-). Metode yang dilakukan untuk pengambilan sampel di lapangan adalah time swim dimana menyelam pada kedalaman 5-10 meter selama kurang lebih 30 menit dan mengambil sampel mucus karang secara acak/random dengan menggunakan siring atau mengambil sampel secara langsung pada karang (fraksi cabang) pada lokasi yang sama. Sampel dianalisis dengan proses isolasi bakteri di laboratorium. Hasil penelitian menunjukkan bahwa pada Mei 2010 bakteri gram positif lebih mendominasi dari gram negatif, sebaliknya Agustus 2011 bakteri gram negatif yang lebih dominan dari gram positif. Indikasi faktor penyebab terjadinya bakteri gram positif yang lebih dominan khususnya di tahun 2010 ialah fenomena La-Nina yang terjadi selama periode tersebut. Perubahan suhu rata-rata yang terjadi pada kedua musim tersebut menjadi salah satu faktor yang merangsang pertumbuhan kedua kelompok bakteri ini. Perlu dilakukan penelitian lebih lanjut khususnya dalam menentukan jenis bakterinya dan pengambilan sampel pada setiap musim.
\end{abstract}

Kata kunci: bakteri, Scleractinian coral, gram positif dan negatif, La-Nina.

\section{ABSTRACT}

Research on Scleractinian Coral with bacteria contamination is relatively few explored in Indonesia. The research study was located in Bunaken National Park in period May 2010 and August 2011. Research focused on gram positive (+) and gram negative (-) bacteria. For sampling procedure by using SCUBA equipment with time swim at depth 5-10 meters at least 30 minutes and collected randomly coral mucus. In the Laboratory samples were anlayzed by Isolation bactery processes. Results show that in May 2010 gram-positive bacteria were more dominant than gram-negative, whereas in August 2011 gram-negative bacteria were more dominant than gram-positive. Indications factors causing the dominancy of gram-positive bacteria, especially in the year 2010 was the La-Nina phenomena that occured during this period. Changes in average temperature that occur in both seasons are the one of factors that stimulates the growth of these two groups of bacteria. Further research needs to be done, especially in determining the type of bacteria and sampling of each season.

Keywords: bacteria, Scleractinian coral, gram positive, gram negative, La-Nina.

\section{PENDAHULUAN}

Terumbu karang merupakan ekosistem yang mewakili khususnya keanekaragaman hayati laut di planet ini, akan tetapi habitatnya di dunia mengalami penurunan secara drastis akibat ulah manusia yakni eksploitasi secara berlebihan, polusi, perubahan iklim dan timbulnya penyakit (De'ath et al., 2009; Hoegh-Goeldberg et al., 2007). Ekosistem terumbu karang yang mengalami penurunan luas penutupan karang adalah akibat kejadian penyakit karang yang timbul di bagian Indo-Pacific (Raymond et al., 2005; Myers \& Raymond, 2005; Willis et al., 2004; Sato et al., 
2009; Haapkyla et al., 2010) dan berdasarkan laporan tahunan terjadi kurang lebih $1 \%$ dan meningkat 2\% diantara tahun 1997 dan 2003 (Bruno \& Selig, 2007). Penyakit pada karang mempunyai kontribusi yang signifikan terhadap menurunnya kondisi ekosistem terumbu karang (Harvel et al., 2004). Beberapa patogen yang berkembang pada ekosistem terumbu karang adalah bakteri, virus dan jamur (Weil et al., 2006; Muller et al., 2012). Penurunan luas tutupan karang juga dapat distimulasi oleh situasi ekstrim yang terjadi akibat dominasi alga pada suatu ekosistem sehingga mengakibatkan menurunnya luasan karang hidup (Bruckner \& Hill 2009, Aronson \& Precht, 2011).

Berlimpahnya serta beranekaragamnya komunitas mikroorganisme prokariotik yang bersimbiosis pasif dengan terumbu karang terjadi jika kondisi lingkungan sekitarnya terganggu (Santavy, 1995; Kushmaro et al., 1996; Santavy \& Peters 1997; Rohwer et al., 2002). Salah satu adaptasi yang dilakukan oleh biota karang adalah mensekresikan cairan atau lapisan mucus atau mucopolysacharide layer yang mengandung glycoprotein, hydrated yang membentuk gel viscoelastik (Ritchie \& Smith, 1997). Ritchie \& Smith (1997) menjelaskan bahwa sekresi mucus akan berubah secara kuantitas serta kandungan alaminya jika karang mengalami stres. Beberapa komunitas mikroorganisme prokariotik tersebut bersifat patogen bagi hewan karang. Keberadaan lapisan mucus ini memberikan ruang bagi mikroorganisme prokariotik salah satunya adalah bakteri untuk bersimbiosis dengan karang.

Penyakit (disease) pada biota karang dapat disebabkan oleh mikroorganisme pathogen, tekanan lingkungan, dan melemahnya biota karang akibat kehilangan sistem imunitas inangnya. Bourne et al. (2009) menyebutkan bahwa komplek simbiosis antara hewan karang, algae endobiotik dan beranekaragam mikroorganisme prokariotik dapat mengganggu integritas "coral holobiont". Kejadian tersebut dapat merangsang terjadinya pemutihan atau bleaching. Komunitas bakteri yang berasosiasi dengan biota karang telah banyak diketahui memiliki diversitas dan kelimpahan yang tinggi (Ritchie \& Smith 1995, 1997; Santavy, 1995; Kushmaro et al., 1996; Santavy \& Peters, 1997; Rohwer et al., 2002; Frias-Lopez et al., 2002). Dinamika komunitas bakteri mengeksploitasi sejumlah ruang pada hewan karang termasuk mucus yang dihasilkan pada permukaan karang, ruang atau relung intraselluler di dalam jaringan hewan karang, ruang pada rangka hewan karang dan air laut di sekitarnya (Raina et al., 2009).

Rohwer et al. (2002) berhasil mengisolasi bakteri (mikroorganisme prokariotik) yang bersimbiosis pada tiga karang yaitu Montastraea franksi, Diploria strigosa dan Porites astreoides dari dua lokasi terpisah dan menemukan tingginya keanekaragaman mikroba dengan beberapa bentuk bakteri yang bersiombiosis pada karang. Salah satu metoda sederhana untuk mengelompokkan tingginya keanekaragaman bakteri menurut Pelczar \& Chan (2005), yaitu dengan teknik pewarnaan gram. Metode tersebut dapat mengelompokkan bakteri menjadi bakteri gram positif dan bakteri gram negatif berdasarkan pada perbedaan dari komposisi dan struktur dinding selnya.

Bakteri gram-negatif adalah bakteri yang tidak mempertahankan zat warna metil ungu pada metode pewarnaan Gram. Bakteri gram-positif akan mempertahankan warna ungu gelap setelah dicuci dengan alkohol, sementara bakteri gramnegatif tidak. Pada uji pewarnaan Gram, suatu pewarna penimbal (counterstain) ditambahkan setelah metil ungu, yang membuat semua bakteri gram-negatif menjadi berwarna merah atau merah muda. Pengujian ini berguna untuk mengklasifikasikan kedua tipe bakteri ini berdasarkan pada perbedaan struktur dinding sel mereka. Banyak spesies bakteri gram-negatif yang bersifat patogen, yang berarti mereka berbahaya bagi organisme inang. Sifat patogen ini umumnya berkaitan dengan komponen tertentu pada dinding sel gram-negatif, terutama lapisan lipopolisakarida (dikenal juga dengan LPS atau endotoksin).

Bakteri gram negatif mempunyai struktur dinding sel berlapis tiga dengan ketebalan yang tipis berkisar antara 10-15 $\mathrm{nm}$. Komposisi dinding sel bakteri gram negatif ini terdiri dari lipid dan peptidoglikan. Konsentrasi lipid pada dinding sel bakteri gram negatif berkisar antara 11-22\%. Bakteri gram negatif umumnya kurang rentan terhadap penisilin, kurang resisten terhadap gangguan fisik, dan persyaratan nutriennya relatif sederhana (Pelczar \& Chan, 2005). Kurangnya informasi terkait dengan kelompok bakteri yang 
menyebabkan beberapa peristiwa penyakit (disease) dan pemutihan karang (bleaching) yang terjadi pada beberapa ekosistem terumbu karang di perairan Indonesia telah mendorong dilakukannya penelitian ini.

Penelitian ini bertujuan untuk: (i) mengidentifikasi komposisi bakteri gram positif dan bakteri gram negatif rata-rata periode Mei 2010 dan Agustus 2011; dan (ii) menentukan perbedaan kelompok bakteri mana yang paling dominan dari 2 periode tersebut.

\section{BAHAN DAN METODE}

\section{Lokasi Penelitian}

Pengambilan sampel dilakukan pada Mei 2010 dan Agustus 2011 di salah satu pulau di Taman Nasional (TN) Bunaken, Sulawesi Utara $1^{\circ} 40^{\prime} 0^{\prime \prime} \mathrm{N}, 124^{\circ} 39^{\prime} 0^{\prime \prime} \mathrm{E}$ yakni di Pulau Bunaken di 6 lokasi berbeda (Gambar 1).

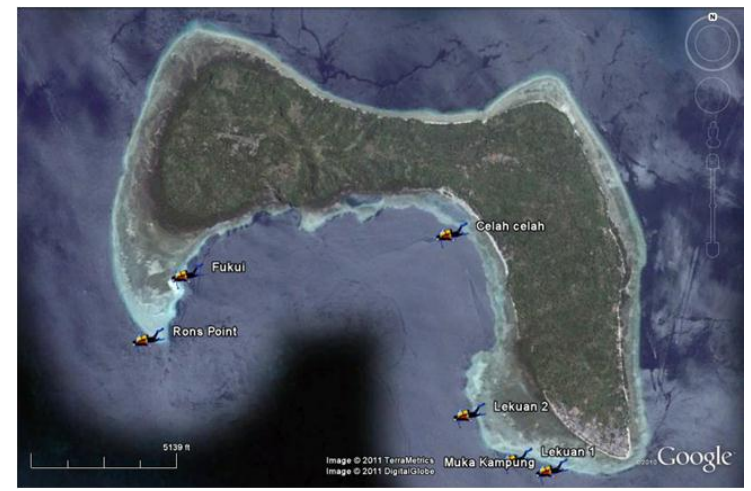

Gambar 1. Peta lokasi pengambilan data di Pulau Bunaken Figure 1. Location data acquisition in Bunaken Island

Sumber: Google, 2011

\section{Pengambilan Data Lapangan}

Pengambilan sampel mucus dilakukan secara acak/random pada kedalaman 5-10 m dengan menggunakan peralatan SCUBA diving dengan metode time swim. Untuk menganalisis bakteri gram + dan gram - pada karang keras yang mengalami pemutihan (bleaching) dan penyakit (disease). Mukus karang diambil dengan menggunakan siring (Gambar 2) dan disimpan dalam ziper bag yang kemudian dibawa ke laboratorium untuk dianalisis (Gambar 3).

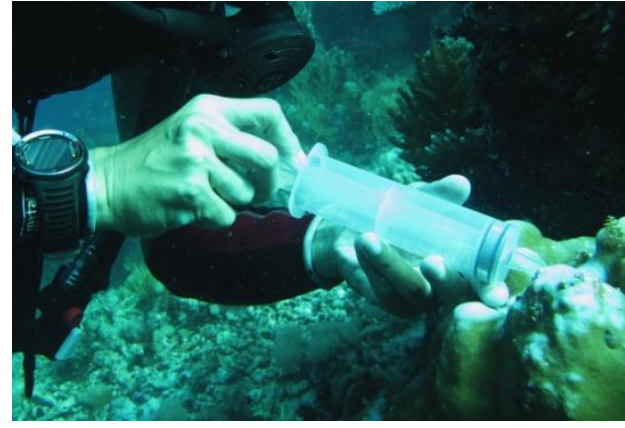

Gambar 2. Pengambilan mukus pada karang dengan menggunakan siring.

Figure 2. Sampling of coral mucus by using skim. Sumber: Koleksi pribadi

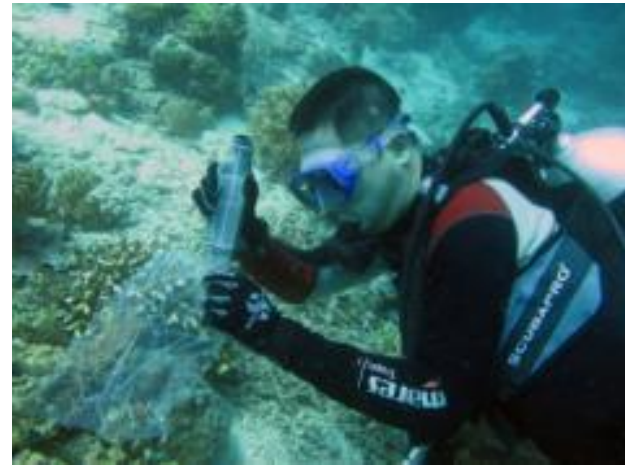

Gambar 3. Sampel mukus disimpan di kantong plastik untuk analisa di laboratorium.

Figure 3. Mucus stored in plastic bags for analysis in the laboratory.

Sumber: Koleksi pribadi

Metode yang digunakan untuk isolasi bakteri dari karang yang mengalami pemutihan dan penyakit adalah metode gores, tuang dan tanam menggunakan media agar dengan urutan kerja sebagai berikut: pembuatan media agar (Gambar 4), isolasi dan isolasi penyegaran bakteri (Gambar $5)$.

Untuk penghitungan nilai total perbedaan gram positif dan negatif dilakukan analisis test statistik dengan uji-T atau $t$-Test yang dipergunakan untuk menguji kebenaran atau kepalsuan hipotesis nol/nihil (Ho) yang menyatakan bahwa diantara dua buah rerata sampel yang diambil secara random dari populasi yang sama tidak terdapat perbedaan yang signifikan (Legendre \& Legendre, 1998). Dari analisis dengan menggunakan t-Test (Tabel 3), didapatkan hasil bahwa ada perbedaan antara bakteri gram + dan gram - dari periode 2 (dua) tahun penelitian yakni pada Mei 2010 gram + (positif) lebih tinggi/dominan, sedangkan Agustus 2011 gram - (negatif) yang lebih tinggi/dominan

Bakteri Asosiasi pada Karang Scleractinia Kaitannya dengan Fenomena La-Nina di Pulau Bunaken - Eghbert Elvan 
dari setiap genus karang keras yang diambil secara acak di 6 lokasi survei.

\section{Isolasi Bakteri pada Sampel Karang dan Mucus Karang}

Isolasi bakteri dari karang yang mengalami bleaching (metode gores, tuang dan tanam) menggunakan media agar dengan urutan kerja sebagai berikut: (i) pembuatan media agar dan (ii) isolasi dan penyegaran bakteri (Pelczar \& Chan, 2005).

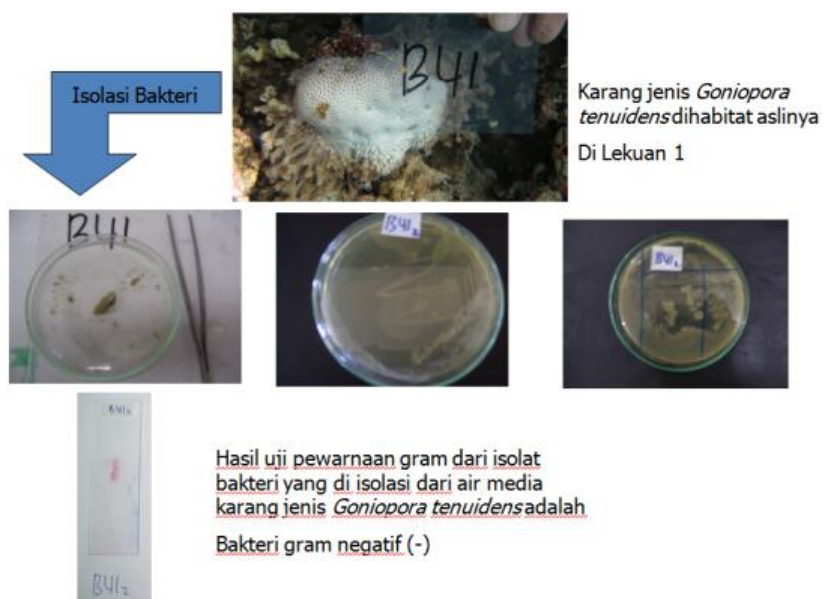

Gambar 4. Proses uji pewarnaan gram dari isolat bakteri.

Figure 4. The process of gram stain test of bacterial isolates

Sumber: Koleksi pribadi

\section{Pembuatan Media Agar}

Proses pembuatan media agar dimulai dengan menimbang dengan timbangan elektrik 10 gram nutrient agar (NA) lalu dimasukkan ke dalam wadah berupa gelas ukur volume $1.000 \mathrm{ml}$, lalu dilarutkan dengan $500 \mathrm{ml}$ aquades kemudian dipanaskan dan diaduk hingga larut. Setelah melarut sempurna, larutan dimasukkan ke dalam cawan petri dengan volume kurang lebih $17 \mathrm{ml}$ dan kemudian disimpan agar memadat pada suhu kamar.

\section{Isolasi dan Penyegaran Bakteri}

Tahapan isolasi dan penyegaran bakteri dimulai dengan menyiapkan sampel karang lunak tanpa pencucian serta cairan mucus yang dihasilkan diletakkan ke dalam cawan petri lalu timbang 0,5 gram sampel, kemudian diletakkan di dalam wadah beaker glass dan diinokulasikan pada media agar yang telah padat dengan metode gores langsung dari sampel karang yang mengalami bleaching, metode tuang untuk cairan mucus yang terdissolved pada air media, serta 0,5 gram sampel yang ditanam langsung pada media agar padat, semua proses isolasi dilakukan dalam ruang atau ruangan khusus. Proses selanjutnya adalah inkubasi selama \pm 24 jam pada suhu $25{ }^{\circ} \mathrm{C}$. Setelah terlihat koloni, kemudian koloni dengan pigmentasi dan morfologi yang berbeda dipisahkan dan dibuat isolat murninya. Diperlukan proses penyegaran untuk meregulasi pertumbuhan sel bakteri pada media baru sehingga diperoleh isolat bakteri dengan kondisi pertumbuhan yang optimum. Bakteri uji yang akan disegarkan diambil satu ose, lalu digoreskan pada media agar miring yang baru lalu diinkubasikan selama 24 jam.

Isolasi mikroorganisme dari hewan karang dan mukus karang dilakukan seluruhnya di Laboratorium Riset Kelautan (LRK), Balai Riset dan Observasi Kelautan.

\section{HASIL DAN PEMBAHASAN}

Hasil isolasi bakteri dan identifikasi awal dengan teknik pewarnaan gram untuk 18 sampel dari 8 genus karang serta mucus karang yang diperoleh dari 5 titik pengambilan sampel di lokasi penelitian (TN Bunaken) pada Mei 2010 menunjukkan bahwa bakteri isolat yang termasuk ke dalam kelompok bakteri gram positif (13 sampel) dan bakteri gram negatif (5 sampel), juga terlihat bahwa dari genus karang yang sama dengan 3 perlakuan isolasi menunjukkan kelompok bakteri yang berbeda seperti yang terlihat pada Porites nigrescens dari lokasi Rons Point (Tabel 1). Frias-Lopez et al. (2002) menemukan bakteri yang berada di kolom perairan berbeda dengan bakteri yang berasosiasi pada karang. Beberapa hasil penelitian yang dilakukan oleh Santavy (1995), Frias-Lopez (2002) serta Rohwer et al. (2002) menunjukkan keanekaragaman kelompok bakteri yang bersimbiosis pada biota karang.

Hasil identifikasi dengan metode pewarnaan gram dari mikroorganisme yang berhasil diisolasi disajikan dalam Tabel 1 (2010) dan Tabel 2 (2011). Isolat bakteri dari karang jenis Porites nigrescens termasuk dalam kelompok bakteri gram positif untuk bakteri yang diisolasi dengan metode gores langsung dari air media hidupnya, sedangkan 
untuk metode gores dari karang dan potongan karang yang ditanam pada media agarnya diketahui termasuk ke dalam kelompok bakteri gram negatif. Hasil yang sama juga dijumpai pada jenis Pocillopora verrucosa dari lokasi pengambilan sampel di Celah Celah. Pada penelitian Efrony et al. (2007) terhadap karang jenis Pocillopora damicornis dan Favia favus ditemukan adanya indikasi infeksi oleh bakteri jenis Vibrio coralliilyticus dan Thalosomonas loyaeana dari kelompok bakteri gram negatif yang menyebabkan terjadinya bleaching dan lissis jaringan serta penyakit the white plague.

Jenis Goniopora tenuidens dari lokasi Lekuan 1 dan Montipora danae dari lokasi pengambilan di Celah Celah menunjukkan kelompok bakteri gram negatif untuk isolat yang dilakukan dengan melakukan goresan dari air media hidupnya. Kelompok isolat bakteri gram positif ditemukan pada lokasi pengambilan sampel karang dan mukus karang yaitu Rons Point, Celah Celah, Lekuan 1, Lekuan 2, Muka Kampung dan Fukui.

Hasil isolasi bakteri dan identifikasi awal dengan teknik pewarnaan gram untuk 25 sampel dari 8 genus karang serta dari mucus karang yang diperoleh dari 6 titik pengambilan sampel pada lokasi penelitian (TN Bunaken) pada Agustus 2011 menunjukkan bahwa bakteri isolat termasuk ke dalam kelompok bakteri gram positif (9 sampel) dan bakteri gram negatif (16 sampel). Isolat bakteri dari karang jenis Porites termasuk dalam kelompok bakteri gram negatif untuk bakteri yang diisolasi dengan metode gores langsung dari air media hidupnya, metode gores dari karang dan potongan karang yang ditanam pada media agar. Hasil yang sama juga dijumpai pada jenis Favites $s p$ dari lokasi pengambilan sampel. Penggunaan metode untuk mendapatkan isolat bakteri yang berbeda dilakukan untuk melihat keanekaragaman kelompok bakteri di sekitar lokasi pengambilan sampel.

Kelompok bakteri gram negatif menginfeksi genus karang lebih tinggi pada 2011 (Agustus), kondisi sebaliknya terjadi pada 2010. Perbedaan kelompok bakteri yang ditemukan pada kedua musim (peralihan I dan Monsoon II) mengindikasikan bahwa perbedaan temperatur telah menjadi salah satu faktor yang merangsang perkembangan kedua kelompok bakteri yang berbeda (Banin et al.,
2000). Pada pertengahan 2010 terjadi La Nina yang berdampak pada terjadinya musim hujan di beberapa wilayah Indonesia, hal ini terlihat pada bulan-bulan pertengahan pada 2010 yang seharusnya berlangsung musim kemarau namun sebaliknya turun hujan deras di berbagai daerah.

Tabel 1. Hasil identifikasi bakteri total dengan metode pewarnaan gram positif dan negatif pada Mei 2010

Table 1. The results of total bacterial identification with positive and negative gram stain method in May 2010

\begin{tabular}{lcccc}
\hline \multicolumn{1}{c}{ Genus } & $\begin{array}{c}\text { Gram }(+) \\
\mathbf{2 0 1 0}\end{array}$ & $\mathbf{\%}$ & $\begin{array}{c}\text { Gram }(-) \\
\mathbf{2 0 1 0}\end{array}$ & $\mathbf{\%}$ \\
\hline Acropora & 3 & 33 & 1 & 6 \\
Favites & 0 & 0 & 0 & 0 \\
Seriatopora & 0 & 0 & 0 & 0 \\
Stylophora & 0 & 0 & 0 & 0 \\
Porites & 8 & 89 & 0 & 0 \\
Goniopora & 1 & 11 & 3 & 19 \\
Montipora & 1 & 11 & 1 & 6 \\
Pachyseris & 0 & 0 & 0 & 0 \\
\hline Jumlah Genus & $\mathbf{1 3}$ & 144 & $\mathbf{5}$ & 31 \\
\hline Sumber: Hasil pengolahan data & & &
\end{tabular}

Sumber: Hasil pengolahan data

Tabel 2. Hasil identifikasi bakteri total dengan metode pewarnaan gram positif dan negatif pada Agustus 2011 Table 2. The results of total bacterial identification with positive and negative gram stain method in August

\begin{tabular}{lcccc}
\multicolumn{5}{c}{2011} \\
Genus Karang & $\begin{array}{c}\text { Gram (+) } \\
\mathbf{2 0 1 1}\end{array}$ & $\mathbf{\%}$ & $\begin{array}{c}\text { Gram (-) } \\
\mathbf{2 0 1 1}\end{array}$ & $\mathbf{\%}$ \\
\hline Acropora & 2 & 22 & 3 & 19 \\
Favites & 0 & 0 & 2 & 13 \\
Seriatopora & 3 & 33 & 2 & 13 \\
Stylophora & 1 & 11 & 5 & 31 \\
Porites & 0 & 0 & 4 & 25 \\
Goniopora & 0 & 0 & 0 & 0 \\
Montipora & 1 & 11 & 0 & 0 \\
Pachyseris & 2 & 22 & 0 & 0 \\
\hline Jumlah Genus & $\mathbf{9}$ & 100 & $\mathbf{1 6}$ & 100
\end{tabular}

Sumber: Hasil pengolahan data

Sifat hujan selama musim hujan pada 2011/2012 di sebagian besar daerah yaitu 267 ZOM $(78,07 \%)$ diprakirakan normal dan $40 \mathrm{ZOM}(11,70 \%)$ atas normal, sedangkan yang bawah normal $35 \mathrm{ZOM}$ $(10,23 \%)$. Kecenderungan cuaca di Indonesia pada 2011 relatif stabil (www.bmkg.go.id). Berdasarkan data dari BMKG tersebut diketahui bahwa pada 2010 telah terjadi La Nina yang berimbas pada tingginya curah hujan lalu pada 2011 ternyata 
kecenderungan curah hujan normal. Data tersebut mengindikasikan bahwa dari tahun 2010 ke 2011 telah terjadi perubahan suhu di sekitar lokasi pengambilan data. Peningkatan suhu sebesar 1-2 ${ }^{0} \mathrm{C}$ dalam jangka waktu yang lama bagi biota karang dapat menstimulasi terjadinya pelepasan zooxanthella dari karang (Jokiel \& Coles, 1990).

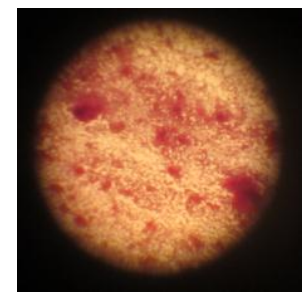

A

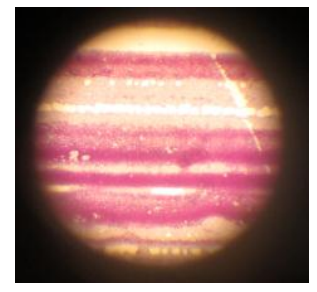

B
Gambar 5. Struktur gram positif $=$ A $(+)$ dan gram negatif $=\mathrm{B}(-)$ dilihat dari mikroskop $=5,5$ Micronmetric (mm).

Figure 5. The structure of gram-positive $=A(+)$ and gram negative $=B(-)$ seen from the microscope $=5.5$ Micronmetric $(\mathrm{mm})$ Sumber: Hasil pengolahan data

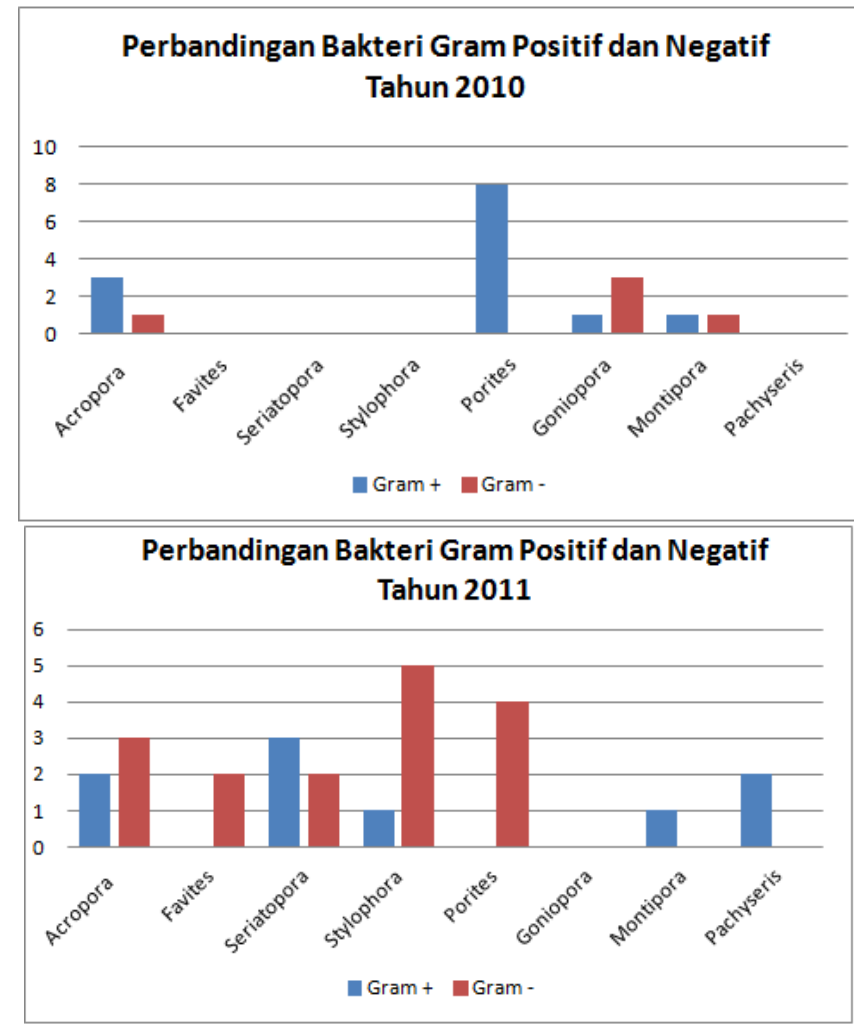

Gambar 6. Grafik perbandingan analisis bakteri gram positif dan negatif 2010-2011.

Figure 6. Comparative analysis graph of gram positive and negative bacteria 2010-2011

Sumber: Hasil analisis
Hasil pengambilan sampel pada dua tahun ini mengindikasikan bahwa perubahan suhu pada lokasi pengambilan sampel telah menjadi salah satu faktor yang menstimulasi berkembangnya kelompok bakteri gram positif dan bakteri gram negatif.

Dari hasil analisis diketahui bahwa pada 2010 ditemukan secara dominan kelompok bakteri gram positif yang memiliki dinding sel lebih tebal dibandingkan dengan gram negatif. Sebaliknya pada 2011yang lebih dominan adalah bakteri gram negatif. Hal ini bisa dilihat pada Gambar 6 tentang perbandingan bakteri gram positif dan negatif pada 2010-2011 (Ampou et al., 2011). Kedua koloni bakteri (gram positif dan gram negatif) teridentifikasi pada kedua waktu pengamatan (pada 2010 dan 2011) dari isolat bakteri pada karang yang mengalami pemutihan dan penyakit. Hasil pengamatan menunjukkan bahwa kedua koloni bakteri yaitu gram positif dan gram negatif berpotensi bersifat pathogen pada karang yang diamati. Pelczar \& Chan (2005) menyatakan bahwa bakteri gram negatif yang bersifat patogen lebih berbahaya dari pada bakteri gram positif, karena membrane luar pada dinding selnya dapat melindungi bakteri dan sistem pertahanan inang dan menghalangi masuknya obat-obatan antibiotik. Senyawa lipopolisakarida pada membran luar bakteri gram negatif dapat bersifat toksik (racun) bagi inang. Menurut Pelczar \& Chan (2005) bakteri laut $95 \%$ adalah bakteri gram negatif, sebagian aktif bergerak sedangkan bakteri gram positif sebagain besar berada pada sedimen. Waktu pengamatan pada 2010 terjadi fenomena La-Nina (berdasarkan data dari BMKG) yang diindikasikan dengan tingginya curah hujan. Tingginya curah hujan pada 2010 mengindikasikan telah terjadinya perubahan kondisi lingkungan di sekitar pengambilan sampel karang yang mengalami pemutihan. Salah satu dampak dari tingginya curah hujan adalah rendahnya tingkat kecerahan di sekitar ekosistem terumbu karang karena teraduknya substrat atau sedimen oleh arus. Terangkatnya sedimen atau substrat akibat meningkatnya kecepatan arus di sekitar ekosistem terumbu karang pada lokasi pengamatan diduga salah satu faktor yang merangsang dominansi koloni bakteri gram positif pada 2010 .

Fenomena yang memicu terjadinya pemutihan dan penyakit pada karang sangat bervariasi dan 
sebagian besar tak terduga dan faktor penyebabnya sangat kompleks (Grimsditch \& Salm, 2006). Faktor-faktor penyebabnya diantaranya adalah: meningkatnya (paling sering terjadi) atau menurunnya suhu air laut, meningkatnya radiasi matahari (Saxby et al., 2003), perubahan kimia air laut (Johnson \& Marshall, 2007), peningkatan sedimentasi (Rogers, 1990), karang terdedah/ terekspose akibat surutnya air laut (Anthony \& Kersewel, 2007) dan infeksi bakteri (Kushmaro et al., 1997). Namun demikian proses kelangsungan hidup dari setiap individu karang sangat tergantung pada kemampuannya untuk beradaptasi dengan perubahan lingkungan di sekitarnya (Grimsditch \& Salm, 2006). Dalam hal ini sangat terkait dengan kemampuan suatu individu dalam ekosistem untuk resistance, yaitu kemampuan ekosistem untuk menahan gangguan tanpa mengalami pergeseran fase atau kehilangan struktur atau fungsinya (Odum, 1989) dan resilience, yaitu kemampuan sistem untuk menyerap atau pulih dari gangguan dan perubahan, tetap menjaga fungsinya (Carpenter et al., 2001).

Tabel 3. Hasil analisis total gram positif dan negatif tahun 2010 \& 2011 dengan Uji-T

Table 3. The results total of analysis gram positive and negative in 2010 \& 2011 with T-Test

t-Test: Paired Two

Sample for Means

\begin{tabular}{lrr}
\hline & Gram + & Gram - \\
\hline Mean & 1.5 & 2 \\
Variance & 1.428571429 & 3.714285714 \\
Observations & 8 & 8 \\
Pearson Correlation & -0.434121571 & \\
Hypothesized Mean & 0 & \\
Difference & 7 & \\
df & -0.529150262 & \\
t Stat & 0.306530076 & \\
P(T<=t) one-tail & 1.894578604 & \\
t Critical one-tail & 0.613060152 & \\
P(T<=t) two-tail & 2.364624251 & \\
t Critical two-tail & & \\
\hline
\end{tabular}

Tolak H0= Ada perbedaan antara gram + dan gram - di 6 titik lokasi survey dimana gram - lebih dominan Sumber: Hasil analisis

\section{KESIMPULAN DAN SARAN}

Pada musim peralihan I (Mei 2010) ditemukan dominan kelompok bakteri gram positif, sedangkan pada Monsoon II (Agustus 2011) adalah kelompok bakteri gram negatif. Perubahan suhu yang terjadi pada kedua musim menjadi salah satu faktor yang merangsang perkembangan kedua kelompok bakteri gram positif dan gram negatif pada lokasi pengambilan sampel. Kurangnya frekuensi penelitian menyarankan agar perlunya dilakukan penelitian pada setiap musim untuk menguji jenis (spesies) bakteri secara lebih detail.

\section{UCAPAN TERIMA KASIH}

Penulis mengucapkan terima kasih kepada Balai Penelitian dan Observasi Laut (BPOL yang sebelumnya bernama Balai Riset dan Observasi Kelautan) atas dukungan dana lewat dana DIPA. Kami berterima kasih juga kepada Kepala BPOL atas saran dan masukkannya, teman-teman Tim Perubahan Iklim, DKP Provinsi Sulut, BTNBunaken dan semua pihak yang mendukung sehingga penelitian ini bisa berjalan dengan baik.

\section{DAFTAR PUSTAKA}

Ampou, E.E., Triyulianti, I., Widagti, N., Hamzah, F. \& Manessa, M.D.M.. (2011). Studi operasional oseaonografi untuk konservasi ekosistem terumbu karang. Laporan Penelitian. Tim Perubahan Iklim, Balai Penelitian dan Observasi Laut.

Anthony, K.R.N. \& Kerswell, A.P. (2007). Coral mortality following extreme low tides and high solar radiation. Marine Ecology Progress Series, 151 (5): 1623-1631. doi:10.1007/s00227-006-0573-0.

Aronson, RB., \& Precht WF. (2001). White-band disease and the changing face of Caribbean coral reefs. Hydrobiologia, 460: 25-38.

Banin, E., Ben-Haim, Y., Israely, T., Loya, Y., \& Rosenberg, E. (2000). Effect of the environment on the bacterial bleaching of corals. Water, Air and Soil Pollution, (123): 337-352.

Bourne, D.G., Garren, M., Work, T.M., Rosenberg, E., Smith, G.W. \& Harvell, C.D. (2010). 
Microbial disease and the coral holobiont. Trends in Microbiology, (12) : 554 - 562.

Bruckner, A.W., \& Hill, R.L. (2009). Ten years of change to coral communities off Mona and Desecheo Islands, Puerto Rico, from disease and bleaching. Diseases of Aquatic Organisms, 87: 19-31.

Bruno, J.F., \& Selig, E.R. (2007). Regional decline of coral cover in the Indo-Pacific: Timing, extent, and subregional comparisons. PLoS ONE 2: e711.

Carpenter, S., Walker, B., Anderies, J.M., \& Abel, N. (2001). From metaphor to measurement: Resilience of what to what? Ecosystems, 4, 765-781.

De'ath, G., Lough J. M. \& Fabricius, K.E. (2009). Declining coral calcification on the Great Barrier Reef. Science, 323: 116-119.

Efrony, R., Loya, L., Bacharach, E. \& Rosenberg. (2007). Phage therapy of coral disease. Coral Reefs, (26): 7 - 13.

Frias-Lopez, J., Zerkle, A.L., Bonheyo, G.T. \& Fouke, B.W. (2002). Par-titioning of bacterial communities between seawater and healthy, black band diseased, and dead coral surfaces. Appl Environ Microbiol, 68: 2214 2228.

Grimsditch, Gabriel D., \& Salm, Rodney V. (2006). Coral reef resilience and resistance to bleaching. IUCN, Gland, Switzerland. $52 \mathrm{pp}$.

Harvell, C.D., Jordan-Dahlgren, E., Merkel, S., Rosenberg, E., Raymundo, L., Smith, G., Weil, E. \& Willis, B. (2007). Coral disease, environmental drivers, and the balance between coral and microbial associates. Oceanograpy, 20: 172-195.

Hoegh-Guldberg, O, Mumby, P.J., Hooten, A.J., Steneck, R.S., \& Greenfield, P. (2007). Coral reefs under rapid climate change and ocean acidification. Science, 318: 1737-1742.

Johnson, J.E., \& Marshall, P.A. (2007). Climate change and the Great Barrier Reef: A vulnerability assessment. Townsville, Qld.: Great Barrier Reef Marine Park Authority. ISBN 978-1-876945-61-9.

Jokiel, P.L., \& Coles, L. (1990). Response of Hawaiian and other Indo Pacific reef corals to elevated temperature. Coral Reefs, 8: 155162.
Kushmaro, A., Loya, Y., Fine, M., \& Rosenberg, E. (1996). Bacterial infection and coral bleaching. Nature, 380:396.

Kushmaro, A., Rosenberg, E., Fine, M., \& Loya, Y. (1997). Bleaching of the coral Oculina patagonica by vibrio AK-1. Marine Ecology Progress Series, 147: 159-165. doi:10.3354/meps147159.

Legendre, L., \& Legendre, P. (1998). Numerical ecology. Elsevier Scientific Publishing Company. $853 \mathrm{p}$.

Muller, E.M., Raymundo, L.J., Willis, B.L., Haapkyla, J., Yusuf, S., Wilson, J.R., \& Harvell, D.C. (2012). Coral health and disease in The Spermonde Archipelago and Wakatobi, Sulawesi. Journal of Indonesia Coral Reefs, 1(3), 149-159.

Odum, E.P. 1989. Ecology and our endangered life-support systems. Sinauer Associates Inc: Sunderland (USA)

Pelczar, M.J., \& Chan, E.C.S. (2005). Dasar-dasar Mikrobiologi 2. Jakarta: UI-Press.

Raina, J.E., Tapiolas, D., Willis, B.L., \& Bournei, D.G. (2009). Coral associated bacteria and their role in the biogeochemical cycling of sulfur. Applied and Environmental Microbiology, (75): 3492 - 3501.

Rogers, S.R. (1990). Responses of coral reefs and reef organisms to sedimentation. Marine Ecology Progress Series, 62: 185-202. doi:10.3354/meps062185.

Rohwer, F., Seguntan, V., Azan, F., \& Knoulton, N. (2002). Diversity and distribution of coral-assosiated bacteria. Marine Ecology Progress Series, 243: 1-10.

Santavy, D.L. (1995). The diversity of microorganisms associated with marine invertebrates and their roles in the maintenance of ecosystems. In: Allsopp D, Colwell RR, Hawks-worth DL (Eds). Microbial diversity and ecosystem func-tion. $\mathrm{CAB}$ International, Wallingford, p 211-229.

Santavy, D.L., \& Peters, E.C. (1997). Microbial pests: coral disease in the Western Atlantic. Proc 8th Int Coral Reef Symp, 1: 607-612.

Saxby, T., Dennison, W.C., \& Hoegh-Guldberg, O. (2003). Photosynthetic responses of the coral Montipora digitata to cold temperature stress". Marine Ecology Progress Series, 248: 85. doi:10.3354/meps248085.

Turak, E., \& De Vantier, L. (2003). Reef building corals of Bunaken National Park, north 
Sulawesi, Indonesia: Rapid Ecological Assesement of biodiversity and status. Final Report to the International Ocean Institute Regional Centre for Australian and the western pacific.

Weil, E., Smith, G., \& Gil-Agudelo, D.L. (2006). Status and progress in coral reef disease research. Diseases of Aquatic Organism, 69(1):1-7.

http://whc.unesco.org/en/tentativelists/2002/. State Minister for The Environment. (2005). Bunaken National Park, diakses pada tanggal, 2 Februari 2012.

http://www.bmkg.go.id/BBMKG_Wilayah_3/Lain_ Lain/Artikel/HUJAN_DI_MUSIM_KEMARA U_DAMPAK_LA_NINA.bmkg. BMKG.

(2010). Diakses pada tanggal 9 Maret 2012. 
